\title{
BİR HAREM BESTEKÂRI SADULLAH AĞA: BİR TARİHI ROMAN İNCELEMESİ
}

\section{Berrin DEMİR}

Özet

Tarihi roman, tarih sahnesinde yaşanmış olayların ve bunlara şahitlik eden ya da yön veren veya bizzat mimarı olan kişilerin günümüz yazarları tarafindan ele alınması ile oluşan edebi bir türdür. Dünya edebiyatında tarihi roman türünün ilk örneği, İskoç yazar Walter Scott'in 1814'te yayımlanan Waverly isimli eseridir. Türk edebiyatının ilk tarihi romanı ise Ahmet Mithat Efendi'nin 1871 yılında kaleme aldığı Yeniçeriler isimli eseridir. Bu edebî eserler geçmişi aydınlatırken geleceğe de yön vermektedir. 1944 yılında Ziya Şakir tarafından yayımlanan Bir Harem Bestekârı Sadullah Ağa isimli eseri, Türk edebiyatındaki tarihi romanlardan biridir. III. Selim döneminde geçen roman, bir yandan padişahın sanata ve sanatçıya ne kadar önem verdiğini gözler önüne sererken, diğer yandan dönemin en başarılı bestekârlarından ve III. Selim'in de gözdesi olan Sadullah A ̆̆a'yı okurla buluşturmaktadır. Bu çalışmada Ziya Şakir'in eseri anlatıcı tipleri, içerik (konu), özet, izlek, zaman, mekân, kişiler, dil ve üslup açısından değerlendirilecektir.

Anahtar Kelimeler: Tarihi roman, izlek, zaman, mekân, üslup

\section{BİR HAREM BESTEKÂRI SADULLAH AĞA: AN ANALYSIS OF HISTORICAL NOVEL}

\begin{abstract}
Historical novel is a literary genre formed by handling the events that took place on the historical scene and people who witnessed or directed or were themselves architects of them by modern writers. The first historical novel in world literature is 'Waverly' by Scottish author Walter Scott, published in 1814. In Turkish literature, the first historical novel is 'Janissaries' written by Ahmet Mithat in 1871. Those literary works illuminate the past and give direction to the future. 'Bir Harem Bestekârı Sadullah Ağa', published by Ziya Şakir in 1944, is one of the historical novels in Turkish literature, too. The novel, set during the reign of III. Selim, shows how much the Sultan gave importance to art and artist; on the other hand, he introduces Sadullah Agha, one of the most successful composers of the era and the apple of III. Selim's eye, to the reader. This study will be analyzed in terms of narrator types, content (subject), summary, theme, time, space, people, language and style, and supported through giving direct references from the novel.
\end{abstract}

Keywords: Historical novel, theme, time, place, style

\footnotetext{
${ }^{1}$ Öğr. Gör. Dr., Kütahya Dumlupınar Üniversitesi, e-posta: berrin.kahraman@dpu.edu.tr, ORCID: 0000-0002-4746-2785
} 


\section{GíRiş}

1883 yılında İstanbul'da doğan Ziya Şakir, eğitim hayatını sürdürürken ilk eseri olan Köylü Kızı'nı, daha sonra da Haydar isimli eserini kaleme almıştır. Pek çok dergiye yazılar yazmış, Terakki mecmuası ile kadınlar ve çocuklarla ilgili gazetelerde başyazarlık yapmıştır. Meşrutiyetin ikinci kez ilanından sonra Aşk ve Vazife ile İstibdat Faciaları isimli vatanî piyesler yazmıştır. Mısır'a gittiği yıllarda Sultan 'ın Gözdesi isimli bir senaryo kaleme almıştır. 22 Kasım 1929 tarihinden itibaren 20 yıllık süre içinde hiçbir maddi ihtirasa kapılmadan 140'1 aşan eser ortaya çıkarmıştır. Z. Melek, Bahtiyar Fenkligil adıyla on üç eseri vardır. Çanakkale Geçilmez, Atatürk'ün Çocukları, Allah'ın Cenneti gibi pek çok senaryoya imza atmıştır. Ayrıca birçok gazetede Hz. Muhammed 'in Hayatı, Kerbala Vak'ası, Din Dersleri gibi bine yakın tarihi makalesi yayımlanmıştır (bkz. Şakir, 2010).

Göğebakan tarafından "tarihte yaşanmış herhangi bir dönem ya da olayı sanatsal bir kaygı ile aktarmak amacıyla gerçeğe yakın bir biçimde işleyen roman türü” (Göğebakan, 2004:15) olarak tanımlanan tarihi romanın gelişim evrelerine geçmeden önce Nurullah Çetin'in tanımına bakmak faydalı olacaktır:

Tarihi roman, geçmişte belirli bir zaman diliminde olup bitmiş olayların, yaşantıların, belirgin dönemlerin, önemli kişilerin hayat hikâyelerinin tarihi gerçekliğe bağlı kalınarak, romancı muhayyilesinde zenginleştirilip yeniden üretildiği metindir. Tarihi romanda olaylar ve kişiler tarihten alınır, ancak bunlar olduğu gibi nakledilmek yerine belirli bir amaca göre yeniden düzenlenir, canlı yaşantı sahnesinde dönüştürülerek sunulur (Çetin, 2011: 220).

Çetin'in de belirttiği gibi tarihi romanlarda tarihin tozlu sayfaları arasında sıkışıp kalmış olay ve kişiler, yazarın yaratıcılığıyla yeniden hayat bulmaktadır. Klasik tarih kitaplarında oldukça üstünkörü anlatılan bir olay/kişi, edebi eserde yazarın canlı anlatımıyla hafızalardan kolay kolay silinmeyecek bir hale gelebilmektedir. Bu durum yeni kuşakların bugünkü yaşamlarını borçlu oldukları tarihsel döneme ilgi duymalarını sağlayacak önemli etkenlerden biri olarak karşımıza çıkmaktadır.

Bozkurt'a göre tarihi romanla ilgili en çok tartış1lan konu ise onun 'gerçekliği'dir. Bunun sebebinin ideolojik olduğu söylenebilmektedir, çünkü tarihi roman edebi geleneğinin çoğunluğunu Cumhuriyet Dönemi'nde olgunlaştırmıştır. Bu alanda eserler ortaya koyan bazı yazarların dönemin olaylarından etkilenmesi ve ideolojik fikirlerin gölgesinden kurtulamamaları, tarihsel olayların çarpıtılarak aktarıldığını göstermektedir. Tarihi roman konusunda uzmanlaşan kişilerin bir bölümü gerçekliğin yaratılırken yazarların özgür olması gerektiği fikrini savunurken diğer bir kısmı da tarihi gerçekliğe bağlı kalınmasını ve kurgunun bu gerçekliğe dayandırılarak oluşturulması gerektiğini düşünmektedir (bkz. Bozkurt, 2018: 129).

Kayalar da benzer minvalde tarihi romanın diğer roman türlerine göre gerçekçi bir roman olduğu görüşündedir. Bu roman türü, ele aldığı zaman dilimini yansıtırken dönemin ruhunu da okura hissettirebilmektedir. Tarihi roman gerçekle sentezlenmiş bir kurguya sahiptir. Dolayısıyla 
tarih sahnesindeki olaylar yeniden inşa edilmez, yazar eserini kurgularken tamamen özgürdür (bkz. Kayalar, 2017: 39).

İbrahim Yılmaz'ın Amin Maalouf'un Tarihi Romanları isimli makalesinde de değindiği gibi tarihî romanlar, tarihi ruhsuz bir anlatı olmanın dışına çıkararak yaşanmış, insanlı bir zaman dilimi hâline getirmektedir. Tarih ancak edebiyat sanatçısının elinde anlaşılabilen, bakılabilen, düşünülüp hissedilebilen bir zaman dilimi hâline gelir (Y1lmaz, 2007: 96). Uzaktan bakıldığında sadece savaş kararları ve barış antlaşmalarından oluşuyormuş izlenimi veren tarih, edebi bir esere zaman/mekân/kişi/tema olarak konuk olunca tarihi olaylar toplum tarafından daha idrak edilebilir bir hâle gelmektedir.

Dünya edebiyatında tarihi roman türünün ilk örneği, İskoç yazar Walter Scott'ın 1814'te yayımlanan Waverly romanıdır. Folkloru ve efsaneleri romanına taşıyan yazar, romanlarında insanı sadece içinde bulunduğu toplumun bir üyesi olarak değil, tarihsel sürecin içinde yer alan biri olarak da ortaya koymuştur. Scott'tan sonra İngiltere'de Charles Dickens İki Şehrin Hikâyesi ve M. Thackeray de Henry Esmond isimli eseri ile bu geleneğe katkı sağlamıştır. 19. yüzyıl Rus edebiyatının tarihi roman alanında en önemli isim Savaş ve Barış isimli romanıyla Tolstoy'dur. Fransa'da ise Notre Dame'ın Kamburu ile Victor Hugo bu alanda öne çıkan isimdir. Amerikan edebiyatında James Fenimore Cooper'ın Deri Çorap Hikâyeleri, milliyetçi reflekslerle kaleme alınan metinlerdeki tarih olgusunun ortaya konması açısından iyi bir örnektir (bkz. Uysal, 2011: 92-96).

Göğebakan, 1789 ve 1814 yılları arasında Avrupa'daki her ülkenin şu ya da bu şekilde bir değişime maruz kaldığının altını çizmektedir. Milletler, bu dönemde meydana gelen işgaller sonucunda oluşan öç alma duygusu ve dönemin baskın özelliği haline gelen milliyetçilik akımı nedeniyle olayları diğer zamanlara nazaran daha farklı bir şekilde algıladılar. Bu bağlamda hem ilk tarihi romanın bu dönemde yazılmış olması hem de en parlak dönemini yine bu yüzyılda yaşamış olması bir tesadüf değil, bilakis bahsedilen sürecin neticesidir (bkz. Göğebakan, 2004: 19).

Türk edebiyatında ise ilk tarihi roman Ahmet Mithat tarafından 1871 yılında kaleme alınan Yeniçeriler' dir. Edebiyat tarihimizde bu roman türü en çok Cumhuriyet döneminde kendini göstermektedir (bkz. Çetin, 2011: 224). Cumhuriyetin ilanıyla yeni bir döneme giren Türk milleti, geride bıraktığ 700 yıllık Osmanlı Devleti'nin padişahlarını, sosyal yaşama damgasını vuran olayları ve önemli sanatçıları eserlerine konu ederek bir tarih bilinci oluşturmaya çalışmıştır. Cumhuriyetin ilanından yaklaşık yirmi yıl sonra yayımlanan ve çalışmamızın esas metnini oluşturan eser, aktarılan III. Selim dönemini ana hatlarıyla okura vererek Mihriban ve Sadullah Ağa'nın aşk hikâyesiyle de ilgiyi üzerine çekmektedir.

\section{Anlaticı}

\subsection{Tanrisal Konumlu Gözlemci Anlatıcı}

Bir Harem Bestekârı Sadullah Ăga isimli tarihi roman, Tanrısal Konumlu Gözlemci Anlatıcı aracılığıyla okura aktarılmaktadır. Nurullah Çetin'e göre bu anlatıcı tipi, olimpik bir konuma, tanrısal bir bakış açısına sahiptir. Kişi ve olayların öncesini ve sonrasını, karakterlerin içinde bulundukları durumları sonsuz bir bakış açısıyla okura iletmektedir (bkz. a.g.e.:107). 
Omniscient anlatıc1, olayları anlatırken ve kişileri tanıtırken üçüncü tekil kişi ağzıyla konuşmaktadır. Her şeyi bilmekte ve olaylara her yönüyle şahit olmaktadır. Kişiler arasında geçen hiçbir olay, tek taraflı olarak değerlendirilmemektedir.

Eserimiz, yazarın Padişah III. Selim, başını kapıya çevirdi (Şakir, 2010: 9) cümlesi ile başlamaktadır. Ana karakterlerden olan padişah, üçüncü tekil şahıs ile okura tanıtılmakla birlikte Mihriban ile konuşmasında birinci tekil kişi ile konuşmaktadır. III. Selim ve kendisine ayrı bir düşkünlüğü olan Mihriban arasında geçen diyalog, samimi bir dille verilmiştir: -Gel Mihriban. Kaç gündür, seni pek özlemiştim./-Aslanım! Mademki özlediniz, ferman buyurmalıydınız./- Sitem edersin, Mihriban. Fakat gaileden hali kalınmıyor ki. Gel şuraya yanıma gel... (bkz. a.g.e.:9).

Kitabın giriş kısmından alınan bu diyaloglar, her iki şahsın hal ve tavırlarını Tanrısal Konumlu Gözlemci Anlatıcı ile aktarıldığını göstermektedir. Padişahın içi içine sığmayan duygularının sesine yansımasını, yüzünün uzun ve esmer olduğunu, Mihriban'ı yanına çağırırken ki nazik davranışını, Mihriban'ın elinde taşıdığı tepsinin meyve ile dolu olduğu bu anlatıcı tipi ile ortaya çıkmaktadır.

\section{2. İçerik (Konu) ve Özeti}

İncelenen bu tarihi romanda, III. Selim döneminde yaşamış bir harem bestekârı olan Sadullah Ağa'nın padişahın haremindeki en gözde kızlardan biri olan Mihriban'a olan aşkı konu edilmektedir. Ancak bu aşk konu edilirken okur, III. Selim'in bir padişah olarak yönetici kişiliğini, onun sanata ve sanatçıya ne kadar düşkün olduğunu da öğrenmektedir. Nurullah Çetin, bir eserin konusu oluşturan unsurlara kendi yöntem kitabında şu şekilde değinmektedir:

'Romanc1 ne anlatiyor?' sorusunun cevab1 konuyu verir. Romanın konusu, olayların en kısa bir biçimde özetlenmiş tanımı ve anlattığı şeyin bir hüküm içinde ifadesidir. Bir başka açıdan romana sorduğumuz 'neyi anlatıyor?' sorusuna aldığımız bir iki cümlelik cevaptır. Yani romanda 'denmek istenen değil', 'denilen şey'dir. Bu 'denilen şey', 'denmek istenen'e alt yapı görevi gören bir malzemedir. Kişiler kadrosunun ne zaman, nerede ve nasıl bir olay yaşadıklarının kısaca ifadesidir (Çetin, 2011: 119).

Romanın konusunu özetlemek gerekirse; günlerden bir gün padişah, Küçüksu koyuna fasıla gider. Boğazdan bir şarkı çalınır kulağına. Şarkıyı söyleyen kişiden oldukça etkilenir ve onu hemen yanına çağırtır. O kişi, Sadullah Ağa'dır. Bostancı başını karşısında gören adam, bir suç işlediğini düşünerek endişelenir. Saraya getirilen Sadullah Ağa, ilk önce padişah ile aynı ortamda değildir. Selim, bir şarkı ister ve yan odadan dinlediği şarkıdan çok etkilenir. Onu Enderun Çavuşluğuna atar.

35 yaşında olan Sadullah Ağa, kardeşi Fatma ile yaşayan, babasına kalan mal-mülk ile ilgilenen, saz âlemlerine giren, musikiye gönül vermiş, etrafındaki insanlar tarafından da takdir gören kendi halinde yaşayıp giden biridir. Enderunda musiki eğitimine devam eden Sadullah, birçok ilahi, semai, şarkı ve türkü öğrenir. Kısa zamanda kendini gösteren bestekâr, küme fasıllarının başkişisi olan Sait Bey ile de dost olur. Küme fasıllarında söylediği şarkılarla padişahı kendinden geçirir. 
Haremdeki kızlar da bir gün bir fasıl heyeti kurmak istediklerini padişaha bildirirler. Padişahın haremine dışarıdan hiçbir erkek hiçbir koşulda girememektedir. Ancak Sait Bey, edepli biri olduğundan dolayı bu iş için Sadullah Ağa'yı önerir. Bundan önce musiki işlerinde Dilhayat Kalfa ilgilenir, bir rakibi vardır, o da Misırlı bir dilber olan Mihriban'dır. III. Selim, Mihriban'a çok düşkündür, ama Mihriban yerini bildiği için çekingen davranmaktadır.

Mihriban ve Sadullah Ağa, haremde musiki çalışırken birbirlerinden duygusal anlamda etkilenmeye başlarlar. Mihriban, Sadullah Ağa'nın bakışlarını, padişahın şarkı sözlerinden bile daha anlamlı bulur. Bir gün Sadullah, padişahın yazdığı ve içinde Canım, cananım Mihribanım sözleri geçen bir şarkıyı Mihriban'a öğretilmesi istenince, şarkıyı birlikte söylemeye başlarlar. İkili arasındaki tüm duygular ortaya çıkar, ancak haremde de dedikodular yayılmaya başlar.

1792'de bir Mevlevi dergâhının açılışına giden padişah, saray erkânı ve harem takımı ile yerini alır. Sadullah Ağa, şarkısını söylerken Mihriban çok duygulanır ve ağlamaya başlar. Saraya döndüklerinde Mihriban ile Sadullah'ın çok uzun süredir birlikte olduklarına dair bir iftira atılır. III. Selim'in emriyle kız zindana atılır, Sadullah Ağa'nın da idamı istenir. Aradan sekiz ay geçtikten sonra bir musiki gecesinde onun bestesi söylenir. Padişah, böyle bir bestekâra kıydığı için pişmanlık duyar. Aslında Sait Bey, padişahın zamanla pişmanlık duyacağını tahmin etmiş ve Ağa'yı kapıcı odasına kilitlemiştir. III. Selim'in isteği üzerine bestekâr huzura gelir. Padişah özür dileyerek insanın bir gün öleceğini ama sanatın hep ebedi olacağını söyler. Mihriban'ı da zindandan çıkartır ve evlenmelerine izin verir.

\section{1. İzlek (Tema)}

İzlek, edebi bir eserde yazarın okura verdiği ileti ya da mesajdır. Tema olarak bilinen bu öğe, eserin temelinde yatan ana düşünce niteliğindedir. Çalışmada adı geçen Bir Harem Bestekârı Sadullah A $\breve{g} a$ isimli tarihi romanın teması sanatın ve sanatçının her zaman ve her yerde korunması gerektiğidir. Verilen bu mesaj sübjektiftir. Çetin, izleğin hangi özellikler taşıması gerektiğini yöntem kitabında açıklamaktadır:

İzlek, romancının romanında söz konusu ettiği gerçek ya da kurgusal ama öznel, tekil bir olaydan genel için geçerli olduğu iddia ettiği bir hükümdür. İzlek, romanın üzerine temellendiği konunun yazarın duygu ve düşüncesinde öznel bir yargı halinde ortaya konan sentezi olup, romanın nihai hedefi ve romancının asıl amacidır. Romanın derin yapısını oluşturan unsurlardan birisi olan izlek, nesnel bir konunun farklı yazarlara göre öznel bir biçimde yorumlanmasıdır (Çetin, 2011: 121).

Bu konuyla ilgili olarak Özcan Gürbüz de yazdığı bir makalede Çetin ile aynı görüşlere sahiptir. Yazarın kaleminden çıkan bir eser, haklı olarak yazarın düşüncelerinin bir ürünüdür. Hiçbir yazar, savunmadığ 1 ya da benimsemediği bir düşünceyi eserinde izlek olarak sunmaz, bu sebeple izleğin ideolojik dolayısıyla da öznel bir yönü olduğuna değinen Özcan'ın cümleleri, aşağıdaki gibidir.

Bir yapıtta tema, bir öykünün vermek istediği temel/öz iletidir. İnsanın bir eylem biçiminin, yaşama karşı takındığı tavrın, tutumun, dolayısıyla 
dünyayı algılayışının, duyumsamasının, yorumlayışının görünümüdür ve kendiliğinden bir yargıyı içerir. Dolayısıyla tema, ideolojik bir içeriğe bürünür (Gürbüz, 2001: 103).

Ziya Şakir, III. Selim döneminin sadece muharebelerden ibaret olmadığını, hem padişahın sanatçı yönüne vurgu yaparak hem de gerek haremde gerekse saray erkânında musikiye düşkün kişilere hayat vererek herkesin bir gün bu dünyadan ayrılacağını ancak sanatın sonsuza dek yaşayacağını, bu sebeple de itinayla korunarak nesilden nesile aktarılması gerektiğini göstermeye çalışmıştır.

\section{Kişiler}

Göğebakan, tarihi roman yazarının eserindeki kişilerini oluştururken iki farklı yöntemi kullanabileceğinden söz etmektedir. Ya yapıtında özellikle başkişi olarak gerçekten yaşamış tarihi kişiliklere yer verecektir ya da Scott'un izinden giderek roman kurgusunu kurmaca roman kişileri yaratarak oluşturacaktır" (Göğebakan, 2004: 41). Çalışmada ele alınan Ziya Şakir'in Bir Harem Bestekârı Sadullah A ̆ga isimli eserinde kişiler tarih sahnesinde yer alan gerçek kişilerdir.

\section{1. Merkezi Kişiler (Ana Karakterler)}

Ana karakterler, bir eserin içinde diğer kişilere göre daha ön plandadır ve eserin konusunu oluşturan olayların büyük bir kısmı bu kişilerin etrafında geçmektedir. Eserin neredeyse tüm ağırlığını sırtlarında taşıyan bu başkişiler, romanın belkemiğini oluşturmaktadır. Nurullah Çetin'e göre ise merkezi kişiler, genellikle özne konumunda olup, diğerleri de onlara göre nesne konumundadır. Bu kişilerin dışında kalanlar yani yardımcı karakterler, merkezi kişiye göre tavır almaktadır, onların etrafında dönerler, onlarla bir şekilde bağlantılıdırlar. Ana karakterlerin sürükleyici, kaynaştırıcı, çekici ve toplayıcı bir rolü vardır (bkz. Çetin, 2011: 146).

\section{1. 1. III. Selim}

III. Selim, Osmanlı Devleti'nin sanata ve sanatçıya en önem veren padişahlarından biridir. Kendisi de sanatkâr ruhlu, şiir ve musikiye düşkün biriydi ve müzik ve tambur dersleri alırdı. Mevlevi tarikatına girdiğinde, yaptığı bestelerle Mevlevi şeyhlerini bile kendine hayran bırakırdı. Sıkıcı devlet işlerinden bunaldığında meşkhaneye giderdi. Batı musikisine çok düşkün olan ve Türk müziğinde birbirine zıt olan üç makamı birleştiren III. Selim, musiki üstatları tarafından hükümdar değil, sanatkâr diye takdim edilirdi. Kendi yazdığı şiirleri de besteleme kabiliyetine sahip olan padişah, sanatçı yönüyle ilgili konularda mütevazı davranır, insanların onu eleştirmesine izin verirdi. Eserde bu durumla ilgili bir anektod aktarılmaktadır:

Bir gün yeni bestelenen bir eseri beğenmedi, ama bir kenara da atmak istemedi. Diğer Musiki üstatlarına da sormak istedi. İsak Efendi" muazzam olmuş" dedi. Padişah çok kızdı "Dalkavukluğun ve riyakârlığın âlemi yok" dedi. Onun bu sanat anlayışı ve ahlakından birçok kişi feyz aldı (bkz. Şakir, 2010: 43-44).

İkiyüzlülüğe ve yalancılığa tahammülü olmayan padişah III. Selim, gerçek hayatta da sanata ilgi duyan, musiki çalışmalarını destekleyen aynı zamanda da bu alana katkı sağlayan bir 
şahsiyetti. Karakaya, III. Selim'in musikiye verdiği önemle ilgili olan makalesinde onu, oldukça açıklayıcı ve toparlayıcı bir cümle ile tanıtmaktadır:

Sanatkâr padişahlar arasında Sultan III. Selim; Osmanlı/Türk müziğini
iyi bilen, bu alanda çok sayıda eserler veren, sanatçıları destekleyen ve
dönemin müzik âlimleri ile yakından ilgilenip onları nazarî (teorik)
açıdan çalışma yapmaları konusunda teşvik eden padişah olarak ilk
sırada yer alır (Karakaya, 2011: 599).

Tarihi romanda ele alınan karakterler, tarihten seçilmektedir. Karakterin kişiliğine dokunulmazken, sadece olaylar kurgusal anlamda değişiklik gösterebilmektedir. Ziya Şakir de tarihi romanın gereklerine uyarak III. Selim'in musikiye düşkünlüğüne ve sanatçı ruhunu eksiksiz yansitmaktadir.

\section{1. 2. Mihriban}

Mihriban, meşhur Udi Prens Ali Rıfat Bey'in elde ettiği bir vesikaya göre, Mısırlı bir bayandır. III. Selim, hareminde olan bu bayana karşı oldukça ilgilidir. Musikiye karşı eğilimi ve yeteneği de olan Mihriban, padişahının isteklerini en iyi şekilde yerine getirmektedir. Saray erkânından olmadığı için yerini bilmekte, hiçbir taşkınlıkta bulunmayan biridir. Eserde Mihriban'ın hem fiziksel hem de hem de karakteristik yapısı övgü dolu sözlerle dile getirilmektedir:

$\mathrm{Bu}$ rakip, Mihriban isminde bir Misırlı dilberdi. Bu dilberin pembe esmer çehresinde, hassasiyetin ateşleri hareleniyordu. Kor gibi parlayan siyah gözlerinde aşk ve ihtirasın alevleri yanıp tutuşuyordu. Mihriban harikulade bir endama malikti. Daha çocuk yaşında rakslara heves etmişti. Az zamanda, seyredenleri hayrete düşüren bir rakkase kesilmişti. Ve genç padişaha takdim edilirken:-Mahir rakkasedir. İktizayı hacette, nazarı hümayunlarına zevki neş'at ve mübarek kalbi şahanenize neş'e ve inbisat verir (Şakir, 2010: 59).

Eserde olaylar, musikiyle çevresine neşe saçan Mihriban'ın etrafında dönmektedir. Hem padişah hem Sadullah Ağa hem de haremde diğer bayanlar ile olan sahnelerde o, hep en ön sıradadır. Güzelliği ve musikideki yetkinliği ile herkesi kendine hayran bırakmaktadır.

\section{1. 2. Sadullah Ağa}

Sadullah Ağa, eserin başlığında da bahsedildiği gibi bir harem bestekârıdır. 35 yaşında hiç evlenmemiştir, kendisi gibi evlenememiş olan Fatma isindeki kız kardeşi ve Pamuk ismindeki carisiyle yaşamaktadır. Birbirine çok düşkün olan bu iki kardeş, her firsatta birbirine destekçidir. Sadullah arkadaşına kalmaya gittiğinde Fatma, kuzum kardeş... Sabah erken gel. Beni merakta koma (a.g.e.:29) diyerek kardeşine olan bağlılığın altını çizmektedir.

Sadullah, o kadar mütevazıdır ki, Topkapı sarayına gittiğinde hiç etrafına bakmaz. Gösterişe alışkın değildir. Ertesi gün Enderun'da önce çırak, sonra çavuş, en son da Ağa ünvanı verilmiştir. Enderunda Sait Bey'in Ăga'ya kahve getirin. Şerbet getirin. Çabuk getirin demesi üzerine, bu iltifatlara hiç alışık olmayan Sadullah Ağa, şaşırıp kalmıştı. Hayatında hiçbir zaman 
büyük insanların arasına karışmamış, daima kendi mütevazı arkadaşları ile yaşamış olduğu için, Sait Bey'in bu muamelelerine ne suretle mukabele edeceğini ve söyleyeceğini bilmiyordu (a.g.e.:38). Terbiyeli davranışlarıyla sarayda odak noktası haline gelerek herkesin güvenini kazanmıştır. Padişah dışında hareme giren tek erkek kendisidir.

Karakteri kadar musiki yeteneği ve eşi bulunmaz sesiyle de saray erkânının gözdesiydi. Bir fasıl gecesinde Sadullah Ağa'nın gür ve davudi edasını duyunca padişah, tamburunu elinden bırakıp gözlerini yumdu, o hoş sesin ruhun derinliklerine işlemesine izin verdi (bkz. a.g.e.: 53). Sadullah Ağa, hem karakter hem de musiki anlamında gönüllerde taht kuran bir şahsiyettir.

\section{2. Yardımcı Kişiler}

\section{2. 1. Sait Bey}

Sait Bey, padişahın hususi hizmetlerinde bulunan ve sarayın en nüfuzlu musahiblerinden ve en önemli musikişinazlarındandır. Padişahın gözdesi ve küme fasıllarının başkişisidir. Musiki meşkhanenin idaresinde görev alan Sait Bey’i III. Selim hiç yanından ayırmazdı. Haremdeki kızlara musiki öğretecek olan Sadullah Ağa'ya güveni tamdı. Padişahın bu şahsa olan ilgisi, onu hemen saray erkanına dahil etmesinden belliydi: Padişah kendisine takdim edilen Sait Bey'in terbiyesini, zarafetini, tavir ve hareketlerindeki inceliklerini ve bilhassa hassasiyetini o kadar takdir etmiştir ki, kendisini derhal maiyetine almıştır (a.g.e.: 48).

\section{2. 2. Dilhayat Kalfa}

Dilhayat kalfa, Sadullah Ağa haremdeki kızlara eğitmenlik yapmaya başlamadan önce oradaki musiki işlerinden sorumlu kişidir. Musikide oldukça başarılıdır. Sadullah Ağa ile Mihriban arasında başlayan aşkı, abartılı bir şekilde iftirada bulunarak herkes tarafindan duyulmasına sebebiyet veren kişidir. Oysa daha III. Selim henüz şehzade iken saraya gelen Dilhayat kalfa, ilk önce okura tanıtılırken oldukça olumlu yönlerinden bahsedilmiştir:

Padişah, zaman zaman Dilhayat ile ilgilenmiş. Musiki ile ilgilenen yaşlı kimselerden ders aldırmıştır. Çok kısa zamanda ilerleme kaydederek beste yapabilecek hale gelmiştir. Şehzade III. Selim'in de gözdesi haline gelmiştir, ancak Dilhatun'un amcası I. Hamit'in muhafazakâr tutumlarından dolayı kendisine karşı çekingen davranıyordu (bkz. a.g.e.:57).

Dilhatun'un bir yandan Sadullah Ağa ile Mihriban arasındaki etkilenmenin adaletsiz bir şekilde ortaya çıkmasında kilit noktayı oluşturması, diğer yandan alıntıda olduğu gibi olumlu yönlerinin aktarılması, her şeyi bilen Tanrısal Konumlu Gözlemci Anlatıcı sayesindedir.

\section{Zaman}

$\mathrm{Bu}$ kavram edebi bir eserde olayların gerçekleştiği zaman dilimlerini karşılayan bir kavramdır. Zaman, romanı oluşturan diğer öğeler kadar önem taşımaktadır. Her nasıl eserde kahramanlar, bu kahramanların deneyimledikleri, kahramanların ve olayların meydana geldiği mekânlar varsa, tüm bu öğelerin var olması için de gün/ay/yı1/yüzyıla yani belirli bir zaman dilimine ihtiyaç vardır. 
Eserimizde olaylar padişah III. Selim döneminde geçmektedir. Bu dönem de 24 Aralık 1761 - 28 Temmuz 1808 tarihlerini kapsamaktadır. Oysa Bir Harem Bestekârı Sadullah A ̆ga adlı bu tarihi roman, Ziya Şakir tarafından 1944 yılında yazılmıştır. O halde Çetin'e göre diyebiliriz ki eserin nesnel zamanı padişahın hayatta olduğu yıllardır (1761-1808). Nesnel zaman, dış dünyanın, evrenin, toplumların yaşamış oldukları, insan bilincinin bir bakıma dışında kalan genel zamandır. Romanın dışında da var olan herkesin paylaştığı ortak zaman dilimdir (Çetin, 2011: 127).

Eserin vaka zamanı ise III. Selim dönemidir. Vaka zamanı, romanda olayların geçtiği zaman dilimidir. Nesnel zamanın tamamın kapsamayan, sadece olayların cereyan ettiği zaman süresidir (a.g.e.:129). Romanda vaka zamanı anlamında eserin son sayfalarına doğru sadece bir yerde, bir tarih kullanılmıştır. O da 1972 yılında Mevlevi Dergâhı'nın tamirini yaptıran III. Selim'in buranın açılışa davet edildiği gündür (bkz. Şakir, 2010: 81). Eserde anlatılanlar, padişahın ömrünün son demlerinde meydana gelmiş bir olay gibi görünmektedir.

Eserin anlatma zamanı ise olayların kitap haline getirilerek okurla buluştuğu zamandır, yani 1944'tür.

\section{Mekân (Uzam)}

\section{1. Kapalı Mekânlar}

Edebi tür olarak roman karakter, tema, olay örgüsü, mekân, zaman gibi ana unsurlardan meydana gelmektedir. Her bir öğe birbirinden farklı olup metin içerisinde birbirlerini destekler niteliktedir. Eserlerde kullanılan uzamlar, yazarlar tarafindan gelişigüzel seçilmemektedir. Her uzamın, kullanılan, sıfatların, edatların ve fiillerin önemli bir işlevi vardır. Tekin'e göre de romancı mekân unsurunu, olayların cereyan ettiği çevreyi tanıtmak, roman kahramanlarını çizmek, toplumu yansitmak, atmosfer yaratmak için kullanmaktadır (Tekin, 2009: 143).

Ziya Şakir'in bu eserinde Sadullah Ağa'nın sesinin ne kadar etkileyici olduğunu anlatmak için bir saray tasviri yapılmıştır. Billur sesinin altından saraya özgü eşyaların, süslemelerin, kısacası dönemin lüks yaşamını yansıtan bir görüntü belirmektedir. Bahsi geçen alıntı aşağıdaki gibidir:

Her nağmesi, engin deniz dalgaları gibi çağlayan Sadullah'ın sesi, sarayın altın yaldızlı işlemeli tavanında, pencerelerin, büyük camlarında, avizelerden sarkan billur parçalarında ahenktar ihtizazlarla akisler yaptıktan sonra, kalplerde coşkun heyecanlar yaratan bir kararla sönüp gidiyordu (Şakir, 2010: 23).

Sarayların yanı sıra Serdap Köşkü de eserdeki kapalı alanlardandır. Farsça kökenli olan 'serdap', eski evlerde bulunan çok sıcak günlerde sığınılan ve yerin altında bulunan bir odadır. Eserde de Serdap Köşkü saray erkanının sıkıntılarından kurtulduğu esenlikli bir ortam olarak karşımıza çıkmaktadır. Şakir, bir yandan mekanın işlevselliğini açıklarken diğer yandan da tarihçesine dair bilgi verir:

Serdap Köşkü, I. Sultan Hamit devrinde bilhassa Valide sultan için yapılmıştı. Yazın sıcak günlerinde, Topkapı sarayının kasvetli 
odalarında bunalan Valide sultan ile diğer gözdeler birkaç saat bu köşke gelirler, Marmara'ya nazır pencerelerin önünde oturarak boğazın serin havasını teneffüs etmekten büyük haz duyarlardı (a.g.e.:46).

Eserde saray ve Serdap Köşkü'nün dışında uzamsal anlamda işlevsellik gösteren musiki meşkhanesinden söz edebiliriz. Romanın başlığını taşıyan ve ana karakterlerimizden olan Sadullah Ağa, sesinin padişah tarafindan beğenilmesiyle saraya davet edilip enderundaki musiki meşkhanesinde görev almaya başlamaktadır. Burası alelade bir ders odası değildi. Musikinin o altın devrinin bir sanat kaynăg halindeydi (a.g.e.:41). Bu meşkhanede pek çok üstat yetiştirmiştir. Sadullah Ağa da bu üstatlardan biridir. Enderun meşkhanesinden feyiz alan Sadullah Ăga'nın sanat ruhu, birdenbire o kadar inkişaf etti ki III. Selim artık onun küme fasıllarına iştiraki için emir verdi (a.g.e.: 45). Her yanı ayrı bir makamla yankılanan musiki meşkhanesi, Sadullah Ağa'nın musiki kariyerini olumlu yönde etkilemiştir. O halde, mekânların insanlar üzerinde etki bıraktığını söyleyebiliriz.

Musiki meşkhanesi, III. Ahmet döneminde inşa edilmiş, ancak yaşanan savaşlar ve siyasi problemler, bu mekâna gölge düşürmüştür. III. Ahmet'ten sonra tahta çıkan III. Selim ise, bu meşkhaneyi eskiden olduğu gibi adeta bir musiki cenneti haline getirmiştir. Buraya feyiz ve revnak (parlaklik) veren, bizzat, III. Selim'di. Bu hükümdar yüksek bir sanatkâr ruhuna malikti. Şehzadeliğinde diğer birçok Osmanlı şehzadeler gibi hayatını serseri bir surette geçirmemiş, şiir ve musikiye hasretmişti (a.g.e.: 42). Verilen alıntıda insanın mekân üzerindeki etkisi görülmektedir. Bu durumda mekân ve insan arasında karşılıklı döngüsel bir etkileşimin olduğunu söylenebilmektedir.

\section{Dil ve Üslup}

\section{1. Dil}

Tarihi romanımızda kullanılan dil, tek tip değildir. Mekâna, kişilere, kişiler arasındaki samimiyete göre değişkenlik arz etmektedir. Haremde kadınlar arasında kullanılan dil ile saray erkânı arasında kullanılan dil aynı değildir. Ya da Sadullah Ağa ile kardeşi Fatma arasında geçen diyaloglar ile Mihriban ile III. Selim arasındaki konuşmalar her ne kadar samimi olsa da, kelime seçimi açısından farklılık göstermektedir. Bir yazarın eserinde kullanması gereken dilin nasıl olması gerektiğini Çetin, bir tavsiye niteliğinde sunmaktadır: Roman dili, romancının sanatkârca bir görüşle, kendine özgü bir biçimde, tamamiyle şahsi tasarruflarlyla ürettiği bir dildir. Romancı sıradan dil unsurlarına hayat vermeli, kanatlandırmalı, onu zengin çağrışım ve imgelerle doldurmal, dili adeta yeniden üretmelidir (Çetin, 2011: 257).

Dil unsurları açısından eserden örnekler vermek faydalı olacaktır. Konuşma dilini, Sadullah Ağa ile Fatma kullanmaktadır. Yalın, kısa ve samimi cümleler dikkat çekmektedir: Bir daha mı? [...] tövbeler olsun, hiçbir yere bırakmam. Evinde otur. Abdestini al. Namazını kıl. Artık dünyada, gözlerimin önünden bir dakika bir ayırmam (Şakir, 2010: 33).

Eser, musikinin öneminden bahsettiği için bu alanda kullanılan terimlerin yer almaması düşünülemezdi. III. Selim'in sanatçı kişiliğinden söz edilirken pek çok terim kullanılmaktadır: III. Selim, yalnız bu eseriyle kalmamıştı. 


\begin{abstract}
"Rastı cedid", "Pesendide", "büzürk" faslından birer "murabba" ve "semai" ile Şevki Turub faslindan bir "kâr" ve bir murabba, "Mahur", "arazbar", "Şehnaz", "Muhayyer Sümbüle”, "Buselik”, "Şehnaz Buselik", "Hüzzam", "Şevki Efza", "Şevki Turub” fasıllarından da cidden üstadane şarkılar yapmıştır (a.g.e.: 43).
\end{abstract}

Eserde Osmanlı dönemine ait bazı kelimeler, günümüzde kullanılmadığı için dipnot ile verilmektedir, bu durum okur için oldukça aydınlatıcı bir durumdur. Bununla birlikte musiki ile kullanılan terimler için de, meraklısına, bilgilendirme amaçlı kitabın en arkasına küçük bir musiki terimler sözlüğü konulabilirdi.

\title{
6. 2. Üslup
}

Üslup, bir kişinin duygu, düşünce ve hayallerini sözle ya da yazıyla kendine özgü bir tarzda ifade ediş biçimidir. Dilin kişiye göre özel bir kullanılış tarzı, bu yolla yepyeni bir dünya kurulmasıdır. Dilin belli bir düzen içinde aldığı şekildir. Her yazarın üslubu, onun dünya görüşünün, hayata bakış açısının, yaşama biçiminin dildeki yansımasıdır. Üslup, yazarın, sanatçının içten gelen samimi duygularının tercümanıdır ve onun şahsiyetinin ifadesidir (bkz. Çetin, 2011: 271-272).

Nurullah Çetin'in yöntem kitabında da belirttiği gibi üslup, yazarlar için ayırt edici bir özelliktir. Çünkü her yazar, ayrı bir dünyadır. Eserlerde kullanılan üslup türü, yazarın öyküyü ele alış biçimini göstermektedir. Bir aşk hikâyesi, lirik bir üslup ile anlatılırken, destansı bir olay epik üslupla aktarılmaktadır. Bunların yanı sıra kitabın yapısına göre mizah, mecazi, eleştirel, hiciv, havas, hitabet üslubu kullanılabilmektedir.

Bir Harem Bestekârı Sadullah A $\breve{g a}$ isimli eserde ise sanatkârane üslup yani duygusal üslup tercih edilmektedir. Roman, bir harem bestekârını anlattığı ve dönemin padişahı da musikiye çok düşkün olduğu için, gerek padişah ve Mihriban gerekse Sadullah Ağa ile Mihriban arasındaki diyaloglar, yalın bir dille ifade edilmemektedir. Cümleler karşılıklı hislerin tercümanı olduğu için, besteler de samimi duygular açısından yoğundur. 19. yüzyıl dönemini anlatan bir romanın da günümüz Türkçesi ile yazılması zaten beklenilmemektedir. Ancak dönemin dilini yansıtan tüm bu aşk dolu sözlere rağmen, eser oldukça anlaşı1ırdır. Yer yer bazı terimler dipnot şeklinde açıklanmıştır. Bu da okurun eseri daha iyi anlamlandırmasına olanak sağlamaktadır.

Duygusal üslup, isminden de anlaşılacağı gibi duyguları ifade ederken kullanılmaktadır. Hayata ve olaylara bir sanatçı gözüyle bakmanın getirdiği bir sonuçtur. Güzellik ve estetik değerler ön plandadır. Yazar eserindeki karakterlerin duygularını dile yansıtır ve özgünlüğünü bu şekilde sağlamış olur (bkz. a.g.e.: 294).

Eserin daha ilk sayfalarında okuru hoş bir musiki karşılamaktadır. III. Selim, Mihriban ve sarayın diğer önde gelenleri boğazda vakit geçirirken bir kayıktan yükselen duygu dolu seda, padişahın dikkatini çekmekte ve Mihriban'ın ellerini avuçlarına alarak dinlemesini söylemektedir. Sadullah Ağa'nın sesiyle hayat verdiği bu bestenin sözleri padişahın duygularına tercüman olmaktadır: Bir pürü cefa, Hoş dilberdir./Müptelaylm, Hayli demdir./Elbet gönül, Arzu eder./Şeftalisi, Her dem terdir./Öpebilsem, Sevebilsem.../Gül yanağl, Her şeb terdir (Şakir, 2010: 13). 
Bir diğer alıntı ise romanın sonuna doğru okurun karşısına çıkmaktadır. Padişah, bir gün kendi yazdığı sözlerin, Sadullah Ağa tarafindan bestelenmesini istemektedir. III. Selim, Mihriban'a olan aşkını bülbül ve gül hikâyesinden esinlenerek dile getirmektedir. Tüm duyguların açıkça ortaya serildiği bu besteyi Sadullah A ğa, Mihriban'a okumaktan çekinmektedir, zira kendisi de aynı duygular içerisindedir. Sadullah emir kuludur, çekine çekine söylemek zorunda kalır. Mihriban'ın da eşlik ettiği dizeler aşağıdaki gibidir: Bülbülü dil, ey gönül rana senindir, sen benim./Berki gülde büyü istiğna senindir, sen benim/Halkai zülfün havası, bendeni mecnun eder./Gönlüm aşifte kılan sevda senindir, sen benim./Ah benim canım, ah benim cananım, Mihriban'ım./ Aman, aman.. Sen benimsin, sen benim (a.g.e.: 73-74).

Yukarıdaki iki alıntı gibi eser pek çok musiki sözüne içkindir. En çarpıcı olanları bu çalışmada yer bulmuştur. Eserde içten duygular, benzetme ve mecaz-1 mürsel gibi söz sanatlarıyla etkili bir şekilde duyulur hale geldiğinden ve mevzu bahis bir aşk hikâyesi olduğundan dolay1 Şakir'in duygusal üslupta eserini kaleme alması oldukça yerinde olmuştur.

\section{SONUÇ}

Bu çalışmada Ziya Şakir'in Bir Harem Bestekârı Sadullah A ̆ga isimli tarihi romanını oluşturan 'anlatıcı tipleri, içerik (konu), özet, izlek, zaman, mekân, kişiler, dil ve üslup' gibi unsurlar, roman inceleme yöntemleri kapsamında ele alınmıştır.

Roman, Osmanlı padişahı III. Selim döneminde yaşamış ve bir harem bestekârı olan Sadullah Ağa'nın Mihriban isimli genç bir kıza âşkını anlatır. Eserdeki olaylar ve kişiler "Tanrısal konumlu gözlemci anlatıcı" aracılığıyla okura aktarılmaktadır. Her şeye hâkim bir üst göz gibi tüm detaylar, üçüncü tekil kişi ile verilmektedir. Romandaki olaylar III. Selim döneminde geçmektedir. Olayların geçtiği mekânlar; saray, köşk, musiki meşkhanesidir. Eserin başkişileri Sadullah Ağa ve Mihriban'dır. Yardımcı kişiler ise musiki meşkhanenin idaresinde görev alan Sait Bey, Sadullah Ağa haremdeki kızlara eğitmenlik yapmaya başlamadan önce oradaki musiki işlerinden sorumlu kişi olan Dilhayat kalfadır. Olaylar ve kişiler arasındaki diyalogların aktarılmasında kullanılan dil çoğunlukla 'günlük' dilken, Sadullah Ağa'nın sanatçı kişiliğinden bahsedilirken daha çok terimlerin yer aldığı bir dil kullanılmıştır. Romanın teması ise sanatın ve sanatçının her zaman ve her yerde korunması gerektiğidir. Eserin geneline hâkim olan konu 'aşk' olunca üslubun da 'duygusal' olması kaçınılmazdır. Bahsi geçen tüm bu kavramlar çalışmada hem ikincil kaynakçalarla hem de eserden verilen doğrudan alıntılarla detaylandırılmıştır. Yapılan bu incelemenin hem Türk edebiyatındaki 'tarihi roman' hem de yazarın kendisi le ilgili yapılacak daha sonraki çalışmalara katkı sağlayacağı düşünülmektedir.

\section{KAYNAKÇA}

Bozkurt, O. (2008). "Reha Çamuroğlu'nun Tarihi Romanları Üzerine Bir İnceleme”. Bartın Üniversitesi Sosyal Bilimler Enstitüsü Türk Dili ve Edebiyatı Anabilim Dalı, Basılmamış Yüksek Lisans Tezi.

Çetin, N. (2011). Roman Çözümleme Yöntemi, (10. Bask1). Öncü Kitap, Ankara. 
Göğebakan, T. (2004). Tarihsel Roman Üzerine. Akçağ Yayınları, Ankara.

Karakaya, O. (2011). “Sultan III. Selim'in 18. Yüzy1l Osmanlı/Türk Müziğine, Teorisine ve Nota Yazım Biçiminin Gelişimine Katkıları”. Türkiyat Araştırmaları Dergisi. 30. Sayı Güz, 597-611.

Kayalar, F. (2017). 'Zülfü Livaneli'nin 'Serenad' ve Tanja Dückers'in 'Himmelskörper' Adlı Tarihsel Romanlarında Toplumsal Bellek”. Atatürk Üniversitesi Sosyal Bilimler Üniversitesi Alman Dili ve Edebiyatı Anabilim Dalı, Basılmamış Doktora Tezi.

Şakir, Z. (2010). Bir Harem Bestekârı Sadullah Ağa. Akıl-Fikir Yayınları, İstanbul.

Tekin, M. (2009). Roman Sanatı. Ötüken Yayınları, İstanbul.

Uysal, Z. (Yay. Haz.). (2011), Edebiyatın Omzundaki Melek/ Edebiyatın Tarihle İlişkisi Üzerine Yazılar. İletişim Yayınları, İstanbul.

Yılmaz, İ. (2007). “Amin Maalouf’un Tarihi Romanları”. A.Ü. Türkiyat Araştırmaları Enstitüsü Dergisi, Say1. 34. Erzurum, 79-97. 